\title{
VARIASI METODE DAN MEDIA PEMBELAJARAN GURU PENDIDIKAN AGAMA ISLAM
}

\author{
Rusiadi \\ Institut Agama Islam Sultan Muhammad Syafiuddin Sambas \\ Corresponding Author e-mail: kandarusiadi@gmail.com
}

\begin{abstract}
The teaching variation component using a variety of methods and variations in the use of media should be implemented optimally by the teacher in delivering subject matter, because in the learning process there are still some students who tend to be passive in carrying out their learning activities. One of the factors that causes these passive students is the lack of variations in methods and media in implementing learning. When the teacher presents the subject matter without using learning media, the communication process between the teacher and students tends to use a one-way pattern. A teacher activity in the context of the teaching-learning interaction process aimed at overcoming student boredom so that in teaching-learning situations, students always show persistence, enthusiasm, and full participation. For that as a teacher, it is necessary to train yourself to master these skills.
\end{abstract}

Keywords: variations in methods, variations in learning media, Islamic education teachers

\begin{abstract}
ABSTRAK
Komponen variasi mengajar dengan menggunakan variasi metode dan variasi penggunaan media semestinya dilaksanakan secara optimal oleh guru dalam penyampaian materi pelajaran, karena dalam proses pembelajaran masih terdapat sebagian siswa cenderung pasif dalam melakukan aktivitas belajarnya. Salah satu faktor yang menyebabkan siswa pasif tersebut adalah kurangnya variasi metode dan media dalam pelaksanaan pembelajaran. Ketika guru menyajikan materi pelajaran dengan tidak menggunakan media pembelajaran, maka proses komunikasi antara guru dengan siswa cenderung menggunakan pola satu arah. Suatu kegiatan guru dalam konteks proses interaksi belajar-mengajar yang ditujukan untuk mengatasi kebosanan murid sehingga dalam situasi belajar-mengajar, murid senatiasa menunjukkan ketekunan, antusiasme, serta penuh partisipasi. Untuk itu sebagai guru perlu melatih diri agar menguasai keterampilan tersebut.
\end{abstract}

Kata Kunci: variasi metode, variasi media pembelajaran, guru PAI

\section{PENDAHULUAN}

Guru tidak hanya dituntut menguasai materi pelajaran, tetapi juga harus memiliki keterampilan di bidang teknologi pendidikan. Antara kemampuan menguasai materi dengan keterampilan di bidang teknologi 
pendidikan memiliki hubungan yang simetris dengan pencapaian tujuan pembelajaran. Menurut Undang-Undang Sistem Pendidikan Nasional Nomor 20 tahun 2003, pasal 40 ayat 2 dijelaskan bahwa Pendidik dan tenaga kependidikan berkewajiban: 1) Menciptakan suasana pendidikan yang bermakna, menyenangkan, kreatif, dinamis dan dialogis. 2) Mempunyai komitmen secara profesional untuk meningkatkan mutu pendidikan. 3) Memberi teladan dan menjaga nama baik lembaga, profesi dan kedudukan sesuai dengan kepercayaan yang diberikan kepadanya.

Berdasarkan amanat Undang-undang Sistem Pendidikan Nasional sebagaimana yang dipaparkan di atas, semua guru termasuk guru Pendidikan Agama Islam harus mampu menciptakan suasana proses pembelajaran yang bermakna, menyenangkan, kreatif, dinamis dan dialogis. Kemudian untuk menciptakan suasana proses pembelajaran yang demikian, konsekuensinya adalah guru tersebut hendaknya mempunyai komitmen terhadap tugas yang diembannya. Tugas mendidik dan mengajar seyogyanya dilaksanakan secara profesional agar mutu pendidikan dan pengajaran berhasil guna bagi peningkatan aspek kognitif, afektif serta psikomotorik peserta didiknya. Mengingat adanya perubahan baru pada sistem pendidikan dan pengajaran, maka setiap guru dituntut untuk meningkatkan profesional di bidang tugasnya.

Adapun persyaratan profesi guru antara lain: 1) Menuntut adanya keterampilan yang berdasarkan konsep dan teori ilmu pengetahuan yang mendalam. 2) Menekankan pada suatu keahlian dalam bidang tertentu sesuai dengan bidang profesinya. 3) Menuntut adanya tingkat pendidikan keguruan yang memadai. 4) Adanya kepekaan terhadap dampak kemasyarakatan dari pekerjaan yang dilaksanakannya. 5) Memungkinkan perkembangan sejalan dengan dinamika kehidupan. (Moh. Uzer Usman, 2001).

Sejalan dengan pendapat di atas, maka dalam melaksanakan proses pembelajaran, sangat diperlukan keterampilan menciptakan kondisi mengajar yang bervariasi untuk pencapaian tujuan pembelajaran yang diharapkan. Komponen variasi mengajar perlu dilaksanakan oleh guru antara lain: variasi metode, variasi pola interaksi dan variasi penggunaan media pembelajaran. Walapun metode ceramah dianggap metode tradisional, tetapi jika diterapkan secara bervariasi, artinya ditambah dengan metode tanya jawab, diskusi dan penugasan, maka suasana belajar siswa menjadi aktif. Penggunaan variasi metode dan variasi media dalam melaksanakan proses pembelajaran menimbulkan dampak positif bagi aktivitas siswa.

Komponen variasi mengajar antara lain: variasi metode dan variasi penggunaan media. Kedua komponen variasi mengajar ini semestinya dilaksanakan secara optimal oleh guru dalam penyampaian materi pelajaran. Namun dalam proses pembelajaran yang masih terdapat sebagian siswa cenderung pasif dalam melakukan aktivitas belajar. Salah satu faktor yang menyebabkan siswa pasif tersebut adalah kurangnya variasi metode dan media dalam pelaksanaan pembelajaran. Ketika guru menyajikan materi pelajaran dengan tidak menggunakan media 
pembelajaran, maka proses komunikasi antara guru dengan siswa cenderung menggunakan pola satu arah.

Pada bagian lain siswa kurang merespon materi pelajaran karena metode penyajian materi tersebut masih terkesan monoton, hal itu disebabkan berbagai faktor, yaitu faktor lemahnya kognitif siswa, proses pembelajaran kurang variasi, materi pelajaran tidak menarik perhatian siswa dan kondisi siswa sudah lelah karena pada jam terakhir.

\section{METODE PENELITIAN}

Jenis penelitian yang dipakai pada penelitian ini adalah penelitian studi kepustakaan (library research) yakni dengan cara mengumpulkan beberapa data dan informasi dari berbagai macam buku maupun literaturliteratur yang ada, dokumen-dokumen maupun catatan-catatan yang erat kaitanya dengan objek penelitian yang sedang diteliti. (Roihan A.Rasyid, 2006).

Sifat penelitian yang dilakukan ini adalah bersifat deskriftif-analisis. Teknik pengumpul data yang digunakan dalam penelitian pustaka yakni dengan teknik pengumpul (inventarisir) data literal yang terdiri data primer, sekunder dan tertier yang ada kaitannya dengan pembahasan. Dengan demikian metode yang dipakai yakni dengan cara mengumpulkan beberapa data dengan melakukan jalan studi kepustakaan.

\section{PEMBAHASAN}

A. Konsep Dasar Variasi Pembelajaran

1. Pengertian Variasi Pembelajaran

Pengertian variasi secara umum adalah adanya keberagaman sesuatu yang terdiri dari bentuk dan sifat yang berbeda-beda antara satu dengan yang lainnya. Istilah variasi dalam pembelajaran mengandung maksud adanya pergantian dan perpaduan metode, media, gaya, situasi, interaksi serta pendekatan pembelajaran sehingga tidak terkesan monoton.

Namun variasi dapat juga diartikan Keanekaan yang membuat sesuatu tidak monoton. Variasi dapat berwujud perubahan-perubahan atau perbedaan-perbedaan yang sengaja diciptakan/ dibuat untuk memberikan kesan yang unik. Misalnya dua model baju yang sama tetapi berbeda hiasannya akan menimbulkan kesan unik bagi masingmasing model tersebut. (Udin S. Winataputra, 2005).

Di dalam kehidupan sehari-hari variasi memegang peranan yang sangat penting, karena tanpa adanya variasi, maka hidup ini mudah mengalami kebosanan. Sebagai contoh: apabila suasana belajar siswa di kelas setiap hari mendengarkan ceramah tanpa adanya pergantian atau tambahan metode lainnya, maka suasana yang demikian dapat menimbulkan kejenuhan dan kebosanan. Oleh karena siswa belajar setiap hari di tempat dan waktu yang bersamaan, maka variasi sangat diperlukan dalam kegiatan pembelajaran. Siswa akan menjadi tidak mudah bosan, jika guru selalu mengajar dengan cara yang bervariasi, baik dalam penerapan metode maupun penggunaan media pembelajaran. 
Komponen pembelajaran yang divariasikan antara lain metode dan penggunaan media. Kedua komponen tersebut memiliki arti penting dalam usaha pencapaian tujuan pembelajaran. Variasi pembelajaran sangat terkait dengan usaha untuk memberikan rangsangan kepada peserta didik agar memiliki motivasi, minat dan perhatian terhadap materi pelajaran yang disajikan.

Kemudian Pengertian variasi pembelajaran adalah Suatu kegiatan guru dalam konteks proses interaksi belajar-mengajar yang ditujukan untuk mengatasi kebosanan murid sehingga dalam situasi belajarmengajar, murid senatiasa menunjukkan ketekunan, antusiasme, serta penuh partisipasi. Untuk itu anda sebagai calon guru perlu melatih diri agar menguasai keterampilan tersebut ( Moh. Uzer Usman, 2001).

Variasi pembelajaran menurut pendapat di atas, merupakan usaha untuk menimbulkan terjadinya proses interaksi antara guru dengan siswa dalam proses belajar mengajar. Kondisi proses belajar mengajar yang monoton menimbulkan kondisi siswa kurang aktif dan tidak merespon materi pelajaran yang disajikan guru.

\section{Pengertian Variasi Metode Pembelajaran}

Semua guru telah mengetahui bahwa proses pembelajaran adalah segala kegiatan yang dilakukan guru untuk membantu siswa dalam pencapaian tujuan belajar. Dalam kegiatan pembelajaran, siswa dianggap telah belajar apabila tujuan pelajaran yang dirumuskan dapat dikuasai siswa. Jadi, pembelajaran adalah segala kegiatan yang dilakukan guru untuk mernudahkan siswa mencapai tujuan yang telah ditetapkan. Sehubungan dengan hal tersebut, tugas guru adalah mengelola materi dan metode pembelajaran, diagnosis kebutuhan dan kemampuan siswa, serta mengelola kegiatan belajar di kelas. Dengan adanya keragaman materi, kebutuhan dan kemampuan siswa, maka diperlukan variasi metode pembelajaran.

Pengertian variasi metode pembelajaran yaitu adanya perpaduan dan pergantian antara satu metode dengan metode lainnya dalam kegiatan pembelajaran. Adanya variasi metode pembelajaran memiliki tujuan untuk, Menghilangkan kebosanan siswa dalam belajar, Meningkatkan motivasi siswa dalam mempelajari sesuatu, Mengembangkan keinginan siswa untuk mengetahui dan menyelidiki hal-hal baru, Melayani gaya belajar siswa yang beraneka ragam, serta Meningkatkan kadar keaktifan/keterlibatan siswa dalam kegiatan pembelajaran (Udin S. Winataputra, 2005).

Proses pembelajaran yang efektif dan efisien dapat terjadi apabila metode pembelajaran bervariasi dan siswa mampu merespon berbagai metode dengan baik. Misalnya ketika guru menyajikan materi pelajaran melalui metode ceramah yang divariasikan dengan penambahan metode tanya jawab, kemudian siswa merespon isi ceramah guru, maka suasana belajar menjadi aktif. Akan tetapi apabila siswa tidak merespon isi ceramah tersebut, maka kegiatan tanya jawab pun tidak efektif. Berbagai variasi yang dilakukan guru dalam menciptakan dan 
memelihara kondisi pembelajaran di kelas, tujuannya adalah untuk efektivitas dan efisiensi tujuan belajar.

\section{Pengertian Variasi Media Pembelajaran}

Media pembelajaran merupakan bagian dari sarana komunikasi dalam kegiatan pembelajaran. Proses komunikasi dalam pembelajaran akan lebih bermakna apabila guru menggunakan media yang relevan dengan tujuan dan metode pembelajaran. Menggunakan media dalam pembelajaran dapat membangkitkan stimulus indera penglihatan dan pendengaran bagi peserta didik. Media pembelajaran sebagai segala sesuatu yang dapat digunakan untuk menyalurkan pesan atau isi pelajaran, merangsang pikiran, perasaan, perhatian dan kemampuan siswa, sehingga dapat mendorong proses belajar mengajar. (R. Ibrahim dan Nana Syaodih S, 2003).

Pengertian media pembelajaran menurut teori di atas adalah segala sesuatu yang dijadikan alat untuk mengkomunikasikan kegiatan pembelajaran. Media pembelajaran dalam hal ini sebagai alat bantu yang digunakan oleh pendidik untuk menyajikan materi pelajaran. Peran guru adalah menyediakan, menunjukkan, membimbing dan memotivasi siswa agar mereka dapat berinteraksi dengan berbagai media yang relevan untuk pencapaian tujuan. Sumber belajar tidak hanya pendidik, tetapi media yang relevan juga dijadikan sumber belajar.

Berdasarkan pengertian media yang dipaparkan di atas, dapat disimpulkan bahwa variasi media pembelajaran adalah penggunaan media yang beraneka ragam bentuknya untuk menyajikan materi pelajaran. Secara garis besar media pembelajaran dapat digolongkan menjadi 3 jenis, yaitu: media visual, audio dan audio-visual.

Jenis media visual merupakan variasi alat bantu pengajaran yang tergolong dalam kelompok ini sangat beragam, seperti gambar-gambar, diagram, grafik, papan, buletin, slide, ukiran, peta, yang semuanya dapat dipakai guru sesuai dengan topik yang sedang dibahas, karakteristik siswa, tujuan pengajaran, ketersediaan alat bantu tersebut, serta yang tak kalah pentingnya, kemampuan guru dalam menggunakannya (Udin S. Winataputra, 2005).

Wujud interaksi antara peserta didik dengan media dapat dilakukan oleh pendidik dengan mempertimbangkan manfaatnya bagi pencapaian tujuan belajar. Penggunaan media pembelajaran juga disesuaikan dengan metode mengajar. Penerapan metode ceramah, tanya jawab, diskusi, resitasi, demonstrasi, bercerita dan praktek, akan lebih bervariasi apabila menggunakan media yang sesuai. Misalnya metode ceramah, hanya dengan mendengarkan saja dapat menimbulkan kejenuhan bagi peserta didik, namun kejenuhan akan berkurang apabila disertai dengan penggunaan media visual.

4. Tujuan variasi dalam pembelajaran

Penggunaan variasi dalam proses pembelajaran menimbulkan dampak positif bagi aktivitas siswa. Adapub tujuan variasi pembelajaran 
adalah untuk menimbulkan dan meningkatkan perhatian siswa kepada aspek-aspek belajar-mengajar yang relevan, untuk memberikan kesempatan bagi berkembangnya bakat ingin mengetahui dan menyelidiki tentang hal-hal yang baru, untuk memupuk tingkah laku yang positif terhadap guru dan sekolah dengan berbagai cara mengajar yang lebih hidup dan lingkungan belajar yang lebih baik, Guna memberi kesempatan kepada siswa untuk memperoleh cara menerima pelajaran yang disenanginya (Moh. Uzer Usman, 2001).

Memperhatikan pendapat di atas bahwa yang menjadi faktor utama pelaksanaan variasi pembelajaran adalah usaha untuk mencapai suasana belajar siswa yang aktif, perhatian, bergairah, merasa senang dan berkembangnya bakat yang dimilikinya. Penggunaan variasi bukan berdasarkan atas kesenangan guru, namun mengacu pada kebutuhan aktivitas belajar siswa dan pencapaian tujuan belajar yang diinginkan.

5. Prinsip variasi dalam pembelajaran

Penggunaan variasi pembelajaran tidak terlepas dari usaha untuk mencapai tujuan yang diharapkan oleh guru dalam pelaksanaan pembelajaran. Oleh karenanya setiap penggunaan variasi dalam menyajikan materi pelajaran, tidak terlepas dari prinsip-prinsip tertentu yang berkaitan dengan keberhasilan proses pembelajaran dan dampak positifnya bagi peserta didik. Prinsip penggunaan variasi pembelajaran adalah sebagai pertama Variasi hendaknya digunakan dengan suatu maksud tertentu yang relevan dengan tujuan yang hendak dicapai, kedua Variasi harus digunakan secara lancar dan berkesinambungan sehingga tidak akan merusak perhatian siswa dan tidak mengganggu pelajaran, ketiga Direncanakan secara baik dan secara eksplisit dicantumkan dalam rencana pelajaran atau satuan pelajaran (Moh. Uzer Usman, 2001).

Sesuai dengan pendapat di atas, prinsip penggunaan variasi dalam pembelajaran, baik variasi metode maupun media pembelajaran antara lain: relevan dengan tujuan pembelajaran, berkesinambungan dan terencana dalam program pembelajaran.

B. Variasi Metode Pembelajaran

Metode adalah cara yang ditempuh untuk mencapai tujuan yang diinginkan. Metode pembelajaran mengandung makna teknik pembelajaran yang dipergunakan guru untuk mencapai tujuan pembelajaran yang diinginkan. Penggunaan metode pembelajaran di samping bertujuan untuk mencapai tujuan pembelajaran yang diinginkan, juga bertujuan untuk menciptakan suasana belajar yang aktif, bersemangat, penuh minat dan adanya interaksi positif bagi perkembangan mental, sikap dan perilaku peserta didik. Untuk mencapai kondisi yang demikian, guru memegang peranan utama dalam menciptakan metode mengajar yang bervariasi dan dalam upaya mencapai tujuan. Oleh sebab itu guru harus memiliki keterampilan mengajar, mengelola tahapan pembelajaran, menggunakan metode yang bervariasi dan menggunakan berbagai media yang sesuai. 
Menggunakan metode dalam proses pembelajaran harus bervariasi, artinya menggabungkan berbagai metode dalam satu pertemuan tetapi tetap mengacu pada prinsip relevansi. Metode mengajar yang sering diterapkan dalam penyampaian materi pelajaran adalah metode ceramah. Walapun metode ceramah dianggap metode tradisional, tetapi jika diterapkan secara bervariasi, maka tujuan pembelajaran akan tercapai dengan optimal.

Jika metode ceramah tidak diselingi dengan metode lainnya, maka kondisi belajar siswa cenderung pasif. Untuk mengaktifkan siswa dalam penerapan metode ceramah, siswa perlu dilatih mengembangkan keterampilan mental untuk memahami suatu proses, yaitu dengan mengajukan pertanyaan, memberikan tanggapan dan mencatat penalarannya secara sistematis. (Abdul Rachman Shaleh, 2000).

Metode ceramah memiliki kelemahan dan kelebihan, kelemahan dari metode ceramah adalah yang visual menjadi rugi, dan yang auditif (mendengarkan) yang benar-benar menerimanya, kemudian kelemahan lainnya Keberhasilan metode ini sangat bergantung pada siapa yang menggunakannya serta Cenderung membuat siswa pasif. Sedangkan kelebihan dari metode ini, adalah memberi kesempatan pada guru untuk menggunakan pengalaman, pengetahuan dan kearifan, kemudian jika digunakan dengan tepat maka akan dapat menstimulasikan dan meningkatkan keinginan belajar siswa dalam bidang akademik.

Kemudian selain metode ceramah, penggunaan metode tanya jawab juga relevan digunakan untuk menyajikan materi pembelajaran pada mata pelajaran Pendidikan Agama Islam. Melalui kegiatan tanya jawab, maka terjadi proses berfikir dan mengeluarkan ide-de atau tanggapan terhadap materi yang menjadi fokus pembicaraan. Tujuan metode tanya jawab antara lain pertama, meninjau pelajaran yang telah lalu, agar siswa memusatkan lagi perhatian terhadap kemajuan yang telah dicapai sehingga dapat melanjutkannya ke pelajaran berikutnya, Kedua Melihat kemampuan murid mereproduksi dengan pertanyaan-pertanyaan yang memacu pada daya ingatan, ketiga Melihat kemampuan siswa berpikir dengan pertanyaanpertanyaan yang memacu daya pikir, keempat Menangkap perhatian siswa agar tertuju kepada pelajaran yang akan disajikan atau dibahas, kelima Memimpin pengamatan dan pemikiran siswa dalam rangka: menemukan bagian-bagian yang penting dari pelajaran yang bersangkutan dan memperkuat atau memantapkan ikatan antara suatu pertanyaan dengan jawabannya, keenam Membiasakan siswa dengan berbagai bentuk pertanyaan sehingga ia tidak merasa asing dengan beragam jenis pertanyaan yang mungkin akan dijumpai dalam kelanjutan belajarnya, dan ketujuh Menyelingi pembicaraan untuk membina suasana kerja samasehingga semua siswa berpartisipasi aktif dalam pelajaran yang akan atau sedang berlangsung (Abdul Rachman Saleh, 2000).

Menggunakan metode tanya jawab dalam proses pembelajaran dapat dilakukan pada kegiatan pendahuluan, inti atau penutupan pembelajaran. Tugas guru yang mendasar pada penerapan metode ini adalah memandu, mengarahkan dan menyimpulkan hasil tanya jawab. Jika tugas tersebut tidak dilaksanakan oleh guru, maka materi akan menyimpang, kurangnya 
respon siswa dan pada akhir proses pembelajaran siswa tidak mampu menyimpulkan hasil tanya jawab.

Kelemahan metode tanya jawab adalah Mempersyaratkan siswa memiliki latar belakang yang cukup tentang topik atau masalah yang didiskusikan kemudian Metode ini tidak tepat digunakan pada tahap awal proses belajar bila siswa baru diperkenalkan kepada bahan pembelajaran yang baru. Sedangkan kelebihannya adalah siswa akan lebih cepat mengerti, karena memberi kesempatan siswa untuk menanyakan hal-hal yang belum jelas atau belum dimengerti sehingga guru dapat menjelaskan kembali serta mengembangkan keberanian dan keterampilan siswa dalam menjawab dan mengemukakan pendapat.

Selanjutnya penggunaan metode diskusi yang cenderung mengkondisikan siswa sebagai subyek dalam proses pembelajaran dan menciptakan suasana belajar yang demokratis. Kriteria pemilihan materi yang akan disajikan melalui metode diskusi menurut antara lain: pertama, apabila ada soal-soal (masalah) yang sebaiknya pemecahannya diserahkan kepada murid-murid, kedua untuk mencari keputusan atau pendapat mengenai sesuatu masalah, ketiga Untuk menimbulkan kemampuan pada anak didik untuk merumuskan pikirannya secara teratur dan dalam bentuk yang dapat diterima oleh orang lain, keempat untuk membiasakan anak didik suka mendengar pendapat orang lain, sekalipun berbeda dengan pendapatnya sendiri dan membiasakan sifat terbuka dan toleran (Zuhairini dkk, 1993).

Metode diskusi merupakan salah satu kegiatan pembelajaran yang terpusat pada siswa. Dengan kata lain bahwa mulai dari pemaparan masalah, presentasi masalah, sampai pada pengambilan suatu kesimpulan terhadap pemecahan masalah dapat dilaksanakan oleh siswa melalui diskusi. Tetapi pada tahap perencanaan diskusi sebaiknya diatur oleh guru sebab terkait dengan jenis materi, tujuan diskusi, pembagian kelompok, pembagian tema diskusi dan waktu pelaksanaan diskusi.

Kemudian metode diskusi memiliki kelemahan diantaranya adalah memerlukan waktu yang cukup panjang, yang kadang-kadang tidak sesuai dengan yang direncanakan kemudian kadang-kadang pembahasan dalam diskusi meluas, sehingga kesimpulan menjadi kabur, dan dalam diskusi sering terjadi perbedaan pendapat yang bersifat emosional yang tidak terkontrol. Sedangkan kelebihannya adalah metode diskusi dapat merangsang siswa untuk lebih kreatif khususnya dalam memberikan gagasan dan ide-ide, kemudian dapat melatih siswa untuk dapat mengemukakan pendapat atau gagasan secara verbal dan melatih siswa untuk menghargai pendapat orang lain dan metode diskusi dapat merangsang siswa untuk lebih kreatif khususnya dalam memberikan gagasan dan ide-ide.

\section{Variasi Media Pembelajaran}

Media pembelajaran sebagai alat komunikasi dapat dikelompokkan ke dalam tiga golongan. Tiga golongan media yang dimaksud adalah 1) Alatalat yang merupakan benda sebenarnya yang memberikan pengalaman 
langsung dan nyata, 2) Alat- alat yang merupakan benda pengganti yang sering kali dalam bentuk tiruan dari benda sebenarnya, 3) Bahasa baik lisan maupun tertulis memberikan pengalaman melalui bahasa.( Sardiman AM, 2000).

Guru Pendidikan Agama Islam harus mampu menggunakan media secara bervariasi, baik media visual mapun audio visual. Keterampilan menggunakan media pembelajaran, memiliki dampak positif baik bagi guru maupun siswa. Media pembelajaran yang digunakan dalam proses pembelajaran harus memperhatikan manfaatnya bagi proses prestasi belajar siswa. Paradigma baru pendidikan dewasa ini terutama pada proses pembelajaran lebih menitikberatkan pada tugas guru adalah sebagai fasilitator. Media atau alat pendidikan akan mempunyai arti penting dalam kegiatan belajar apabila media atau alat yang dipilih benar-benar memiliki relevansi dengan jenis materi, metode dan tujuan pembelajaran. Dalam hal ini dapat disimpulkan bahwa efektivitas, efisiensi dan komunikatif menjadi prioritas dalam penggunaan alat atau media pendidikan. Pertimbangan lain dalam penggunaan media secara bervariasi antara lain: manfaat media bagi pencapaian tujuan pembelajaran, kemampuan guru dalam pengadaan dan penggunaannya serta relevansi antara bahan pelajaran dengan alat yang digunakan.

Adapun variasi penggunaan media menurut Moh. Uzer Usman (2001) adalah sebagai berikut:

1) Variasi alat atau bahan yang dapat dilihat (visual aids): Alat atau media yang termasuk ke dalam jenis ini ialah yang dapat dilihat, antara lain grafik, bagan, poster, diorama, specimen, gambar, film dan slide.

2) Variasi alat atau bahan yang dapat didengar (auditif aids): Suara guru termasuk ke dalam media komunikasi yang utama di dalam kolas. Rekaman suara radio, musik, deklamasi puisi, sosiodrama, telepon dapat dipakai suara sebagai penggunaan indera dengar yang divariasikan dengan indera lainnya.

3) Variasi alat atau bahan yang dapat diraba, dimanipulasi dan digerakkan."

Jenis media visual yang dapat digunakan untuk pembelajaran PAI terdiri dari: transparansi, gambar, chart dan foto. Media tersebut digunakan untuk memvisualisasikan pesan-pesan atau materi pelajaran. Penggunaan media transparansi misalnya LCD proyektor untuk menyajikan materi pelajaran agar guru tidak perlu menulis di papan tulis terutama pada penerapan metode ceramah, tanya jawab dan diskusi. Penggunaan LCD proyektor ketika menyajikan materi pelajaran akan lebih menarik, efektif dan efisien apabila dibandingkan dengan menggunakan papan tulis.

Berkaitan dengan variasi penggunaan media visual, Udin S. Winataputra (2005) menjelaskan: Variasi alat bantu pengajaran yang tergolong dalam kelompok ini sangat beragam, seperti gambar-gambar, diagram, grafik, papan, buletin, slide, ukiran, peta, yang semuanya dapat dipakai guru sesuai dengan topik yang sedang dibahas, karakteristik siswa, 
tujuan pengajaran, ketersediaan alat bantu tersebut, serta yang tak kalah pentingnya, kemampuan guru dalam menggunakannya.

Pada umumnya, alat bantu pengajaran yang dapat didengar dapat mendominasi kelas. Oleh karena itu, suara guru harus cukup mampu menarik perhatian para siswa. Guru harus mampu memvariasikan suaranya, dari tinggi ke rendah, besar ke kecil sedih ke gembira, keras ke lembut, atau dari cepat ke lambat. Guru dapat pula menggunakan berbagai variasi alat bantu yang dapat didengar seperti rekaman suara binatang, pidato, atau suara tokoh-tokoh terkemuka. Variasi dapat pula dibuat dengan meminta siswa membacakan puisi atau wacana tertentu dan bahkan dapat mengundang nara sumber untuk berbicara di depan kelas.

Media audio dapat digunakan di sekolah karena harganya terjangkau dan mudah digunakan, misalnya tape recorder. Media ini digunakan untuk mendengarkan sesuatu yang terkait dengan materi pelajaran. Guru dapat menyajikan bacaan Al-Qur'an, bacaan shalat dan doa-doa melalui kaset tape recorder. Pada zaman ini sudah tersedia kaset audio untuk mendengarkan lagu-lagu yang bernafaskan Islam, ceramah, cerita, belajar membaca Al-Qur'an dan paket-paket lainnya.

Media pembelajaran yang paling menarik untuk digunakan adalah media audio-visual, karena media ini memiliki dua fungsi, yaitu dapat dilihat dan didengar. Variasi alat atau bahan yang dapat didengar, dilihat, dan diraba (audiovisual aids). Penggunaan alat jenis ini merupakan tingkat yang paling tinggi karena melibatkan semua indera yang kita miliki. Hal ini sangat dianjurkan dalam proses belajar-mengajar. Media yang termasuk AVA ini, misalnya: film, televisi, radio, slide projector yang diiringi penjelasan guru, tentu saja penggunaannya disesuaikan dengan tujuan pengajaran yang hendak dicapai."

Menggunakan berbagai media dapat membantu pemahaman peserta didik terhadap materi pelajaran. Mengajar adalah proses bantuan terhadap peserta didik untuk mengembangkan potensi yang dimilikinya Penggunaan media pembelajaran secara tepat akan dapat menumbuhkan dan meningkatkan minat siswa dalam belajar serta kegiatan pembelajaran akan menjadi lebih efektif.

\section{KESIMPULAN}

Metode dan media pembelajaran merupakan dua komponen yang harus diperhatikan oleh guru agama Islam untuk mengimplementasikan materi pembelajaran. Penggunaan metode dan media yang bervariasi dalam pembelajaran, akan memudahkan bagi siswa untuk memahami setiap materi yang disampaikan. Guru agama Islam harus mampu menggunakan metode dan media yang tepat dalam pembelajaran, karena pembelajaran merupakan proses teratur dan terukur untuk mengidentifikasi, menumbuhkan dan mengembangkan pengetahuan siswa. Pengetahuan siswa tidak dapat berkembang jika dalam proses pembelajaran kekurangan metode dan media.

Melaksanakan proses pembelajaran, sangat diperlukan keterampilan menciptakan kondisi mengajar yang bervariasi untuk pencapaian tujuan pembelajaran yang diharapkan. Komponen variasi mengajar perlu 
dilaksanakan oleh guru antara lain: variasi metode, variasi pola interaksi dan variasi penggunaan media pembelajaran. Walapun metode ceramah dianggap metode tradisional, tetapi jika diterapkan secara bervariasi, artinya ditambah dengan metode tanya jawab, diskusi dan penugasan, maka suasana belajar siswa menjadi aktif. Penggunaan variasi metode dan variasi media dalam melaksanakan proses pembelajaran menimbulkan dampak positif bagi aktivitas siswa

\section{DAFTAR PUSTAKA}

Abdul Rahman Shaleh, (2000), Pendidikan Agama dan Keagamaan, Jakarta: Gema Windu Pancaperkasa.

Abin Syamsuddin Makmun, (2002), Psikologi Pendidikan, Bandung: PT. Remaja Rosdakarya.

Ahmad Tafsir, (2001), Metodologi Pengajaran Agama Islam, Bandung: Remaja Rosdakarya.

Depag RI, (1995), Al-Qur'an dan Terjemahannya, Jakarta: Yayasan Penyelenggara Penterjemah Al-Qur'an.

.,(2004), Standar Kompetensi Guru Pendidikan Agama Islam, Jakarta: Dirjen Binbaga Islam.

Depdiknas, (2003) Undang-Undang Sistem Pendidikan Nasional No.20 tahun 2003, Jakarta: Depdiknas Pusat.

Endang Poerwanti dan Nurwidodo, ( 2002). Perkembangan Peserta Didik, Malang: UMM Press.

Hadari Nawawi, (1995), Metode Penelitian Bidang Sosial, Yogyakarta: Gajah Mada University Press.

Ivor. K. Davies, (1991), Pengelolaan Belajar, Jakarta: CV. Rajawali.

Khairawati, dkk (2004) Pedoman Penyusunan Skripsi, Pontianak: STAIN Press.

Lexy J. Moleong, (2002), Metodologi Penelitian Kualitatif, Bandung: PT. Remaja Rosdakarya

Masri Singarimbun, (1995), Metode Penelitian Survey, Jakarta: Pustaka LP3ES.

Moh. Uzer Usman, (2001), Menjadi Guru Profesional, Bandung: PT. Remaja Rosdakaya. 
Muhibbin Syah, (2003), Psikologi Pendidikan dengan Pendekatan Baru, Bandung: Rosdakarya Offset.

Mulyasa, (2005), Kurikulum Berbasis Kompetensi, Konsep, Karakteristik dan Implementasi, Bandung: PT. Remaja Rosdakarya.

Oemar Hamalik, (1995), Kurikulum dan Pembelajaran, Jakarta: Bumi Aksara.

P. Joko Subagyo, (1991), Metode Penelitian Dalam teori dan Praktek, Jakarta: PT. Rineka Cipta.

R. Ibrahim dan Nana Syaodih S, (2003), Perencanaan Pengajaran, Jakarta: PT. Rineka Cipta.

Sapari Imam Asyari, (1981), Metodologi Penelitian Sosial, Surabaya: Usaha Nasional.

Sardiman A.M, (2000), Interaksi dan Motivasi Belajar Mengajar, Jakarta: PT. Rajagrafindo Persada.

Sumadi Suryabrata, (1992), Metodologi Penelitian, Jakarta: Bina Aksara.

Syaiful Bahri Djamarah dan Aswan Zain, (2002), Strategi Belajar Mengajar, Jakarta: PT. Rineka Cipta.

Udin S. Winata Putra, (2005), Strategi Belajar Mengajar, Jakarta: Universitas Terbuka 